\title{
STUDENTS' ATTITUDE TO THE CYNICAL WORDS USED BY THE TEACHER IN THE CLASSROOM
}

\author{
Ade Sarkosih', Duduh Abdulah ${ }^{2}$ \\ ${ }^{1}$ IKIP Siliwangi \\ ${ }^{2}$ IKIP Siliwangi \\ ${ }^{1}$ akossomad123@gmail.com, ${ }^{2}$ duduizar@gmail.com
}

\begin{abstract}
In the second language classroom, the teacher sometimes reminds or rebukes the students' mistake by using cynical word. This word is considered inappropriate because it tends to disparage the students. Thus it can hurt their feeling. This study is aimed to investigate the students' attitude to the cynical words used by the teacher in the classroom interaction. The method used was qualitative. The respondents were students at one vocational school in Batujajar, Bandung. The interview was used as the instrument to collect the data. The question of interview was developed based on the components of attitude. The result showed that the students had positive attitude to the cynical words used by the teacher in the classroom. They thought it was quite effective to remind them about their mistake. Unfortunately, it had negative impact on the students' feeling. The students felt sad and embarrass when the teacher rebuke them in front of their classmate. This indicates the teacher cannot use cynical words too often in the classroom interaction. It is better for them to use the other way that is more appropriate in reminding the students' mistake.
\end{abstract}

Keywords: Attitude, Cynical Words, Classroom Interaction

\section{INTRODUCTION}

For foreign or second language classroom, teacher talk plays an important role in the classroom interaction. Teacher talk itself is defined as the language used by the teacher when addressing second language students in the classroom (Ellis, 1994). It provides the model to the students of how to communicate by using the target language (Pinter, 2006). It also support students while practicing the target language. Then, appropriateness of teacher talk can create warm classroom atmosphere and teacher-students relationship ((Pujiastuti, 2013)).

Teacher talk is divided into two major types: indirect influence and direct influence (Brown, 2001). Regarding the first types, it has indirect impact to both learners' second language acquisition and feeling. The teacher, for example, makes some jokes, ask question or repeat learners' question. Meanwhile, in the second types, the teacher directly response the students talk or behavior. The teacher, for instance, gives direction and information or criticizes students' behavior or response. 
Related to the second type of teacher talk, especially criticize students' response or behavior, the fact showed that most of the teachers sometimes did it excessively. They do not only communicate anger, displeasure, annoyance or dissatisfaction by words or intonation, but also tend to disparage students by using cynical words. The aim is to make the students realize their mistake and change their behavior. However, as a consequences, it will affect the students feeling and motivation in learning the second language. It will also destruct teacher-students relationship.

Based on the above fact, this research would like to investigate the students' attitude to the cynical words used by the teacher. This is important to be conducted as it will bridge the gap between what the students are expected and the fact in the field.

\section{Teacher Talk}

Teacher talk refers to the variety of language used by the teacher while doing interaction with the second language student in the classroom. This is in line with the literal definition of teacher talk in Longman Dictionary of Language Teaching and Applied Linguistic (Richard, 1992), variety of language sometimes used by the teachers when they are in the process of teaching. Ellis, (1994)defines teacher talk as the language used by the teacher when addressing second language students in the classroom. Meanwhile, Richard (1992) says that teacher talk is speech used by the teacher while communicating with the students in the classroom. He adds that the teacher speech sometimes contains special characteristics of target language in order to give a model for the students.

Teacher talk has two types: indirect influence and direct influence (Brown, 2001). Every types has its own feature that can be seen in the following table:

Table 1: Teacher Talk Types by Brown (2001)

\begin{tabular}{lll}
\hline Teacher & Indirect & 1. $\begin{array}{l}\text { Deal with direct feeling: In a non-threatening way, } \\
\text { accepting, discussing, referring to, or communicating } \\
\text { Talk }\end{array}$ \\
understanding of past, present, or future feelings of \\
students.
\end{tabular}

2. Praise or encourages: Praising, complimenting, and telling students why what they have said or done is valued. Encouraging students to continue, trying to give them confidence, confirming that answers are correct

2a. Jokes: Intentional joking, kidding, making puns, attempting to be humorous, providing the joking is not at anyone's expense. (Unintentional humor is not included in this category.) 
3. Uses ideas of students: Clarifying, using, interpreting, and summarizing the ideas of students. The ideas must be rephrased by the teacher but still be recognized as being student contributions

3a. Repeats students' response verbatim: Repeating the exact words of students after they participate.

4. Asks Questions: Asking questions to which the answer in anticipated. (Rhetorical questions are not included in this category.

Direct Influence
5. Gives information: Giving information, fact, own opinion, or ideas: lecturing or asking rhetorical questions

5a. Correct without rejection: Telling students who have made a mistake the correct response without using words or intonation which communicate criticism

6. Give direction: Giving directions, request, or commands that students are expected to follow; directing various drills; facilitating whole - class and small - group activity.

7. Criticizes behavior: Rejecting the behavior of students; trying to change the non-acceptable behavior, communicating anger, displeasure, annoyance, and dissatisfaction with what students are doing.

7a. Criticizes response: Telling the students his or her response is not correct or acceptable and communicating criticism, displeasure, annoyance, rejection by words or intonation.

\section{Cynical}

Cynical refers to developing emotional reactions such as anger, anxiety, stress, shame and even disgust in relation to the organization (Korkut, 2016)). In other words, it deals with negative beliefs about and appraisals of the intentions and motives of other people.

\section{Attitude}

There are various definition of attitude given by some experts. Bohner and Dickel (2011) state that attitude is an evaluation of an object of thought .Allport (1935)defines attitude as a mental 
and neural state of readiness, organized through experience, exerting a directive and dynamic influence upon the individual's response to all objects and situations with which it is related. Baron and Byrne (in (Jain, 2014)) state that attitude as relatively lasting cluster of feelings, beliefs, and behavior tendencies directed towards specific persons, ideas, object or groups. Meanwhile,Myers (1987), p.36) mention attitude as a favorable or unfavorable evaluation toward something or someone, exhibited in our beliefs, feelings or intended behavior. Schiffman \& Kanuk (2004)say that attitude has three components: cognitive, affective and behavior.

From explanation above it can be concluded that attitude is one's evaluation toward something. It deals with three components: 1) Affective, emotional response both of like or dislike towards an attitudes object. 2) Behavior, action toward something. 3) Cognitive, relating to, being, or involving conscious intellectual activity (such as thinking, reasoning, or remembering).

\section{METHOD}

This research used qualitative method. It was conducted at one vocational school in Batujajar Bandung Barat. This school was chosen because most of English teacher in this school used cynical words to correct the students' behavior or response in the classroom.

The respondents were 6 students. In collecting the data, this research used interview. The questions in the interview was developed based on the components of attitudes mentioned by some experts that were cognitive, affective, and behavior. After the data gained, it was then categorized and analyzed based on several theories.

\section{RESULT AND DISCUSSION}

\section{Result}

This part discusses the result of the research. The discussion will be based on the components of attitude that is mentioned in the previous chapter.

\section{Cognitive}

Cognitive deals with opinion or perception. Regarding students' perception to cynical words by the teacher, the interview data shows the following answers:

S1: I thought teachers' cynical words could make me understand my mistake and deficiency. S2: Actually, I was wondering why teacher must use those words to their students. There was another better way to show it.

S3: I thought teacher have their own reason why he used it. Probably he wanted to make me realize my deficiency.

S4: What teacher do was good because it made me realize my deficiency.

S5: There was no problem with cynical word that was used by the teacher. The aim was to change me to be a better person.

S6: It was not good for teacher to use those words.

The interview data revealed that most of students (4 students) thought that cynical words used by the teacher did not become the problem for them. They believed that the teacher used 
it for several reasons, which one of them was to make them realize their mistake. On the other hand, the rest of students thought that there was another way to warn the students about their mistake instead of using cynical words that can harm their feeling.

\section{Affective}

Affective deals with feeling dislike or like. There were two questions that had to be answer by the students at this point. The first one focused on the students' feeling after the teacher used cynical words to them. The answers were given below:

S1: I felt nothing. I just laughed because it made me realize my mistake

S2: I felt angry.

S3: Honestly, I felt sad.

S4: I felt that teacher was really care about my act. It indicated that the teacher monitored my attitude and my progress

S5: I felt embarrass to know my mistake.

S6: I just felt so sad.

The result of interview showed that cynical word used by the teacher had bad impact to the students feeling. Most of students felt sad, embarrass, and angry. In contrast, two students had positive attitude to the cynical words used by the teacher. They felt nothing because it was for their improvement.

The second question deals with whether or not the student felt demotivate while the teacher used cynical words. The answers were depicted below:

S1: No, I do not.

S2: Yes because the teacher did it in front of the class.

S3: No. The teacher used it as a joke.

S4: No, I don't.

S5: No, I don't.

S6: Yes. He did it often. Thus, it made me sad.

Most of the students answers showed that they did not feel demotivate to the cynical words used by the teacher. They realized that the teacher used it as a joke. It could be also seen from their peer response, by which most of them were laughed.

\section{Behaviors}

Behavior is defined as students' action toward cynical words used by the teacher. Alike affective component, there were two question asked in this section. The first one dealt with what the students did after the teacher disparaged them. The answer were given in the following:

S1: I did not do anything.

S2: I was angry to my teacher but I cannot. I just ended with fake smile. 


\section{Volume 1, No. 5, September 2018 pp 624-630 는}

S3: I just kept silent.

S4: I said thanks to my teacher in the end of the class.

S5: I only smiled to my teacher without said anything.

S6: I was angry so I slammed my book and ended with crying.

The result of interview revealed that three of six students did not do anything. Two were basically angry, but they covered it with a fake smile. Meanwhile, one of them demonstrated positive behavior. He/she thanked the teacher for reminding the mistake. This result was quite contrast with the data in affective component by which most of the students felt nothing.

The next question focused on the students' future action after the teacher satirized them. Most of the students' answer showed that they would change their attitude. They would study hard so that the teacher would not disparaged them again. At this case, only one students who admitted that he would not do anything as he had done the best. The excerpt of students' answer can be seen as follow:

S1: Of course I will try to be a better person than before, no doubt.

S2: In order to avoid another insinuation I will try to be a better one.

S3: I will try the best to change my attitude and cover my deficiency.

S4: Indeed, I will try the best.

S5: Of course I am.

S6: I won't change anything! I was doing the best after all!.

\section{DISCUSSION}

This research is conducted to know students' attitude toward cynical words used by the teacher in the classroom interaction. As priory mentioned, attitude contains three components: cognitive, affective, and behavior (Schiffman, \& Kanuk, 2004). The result of this research shows that most of students had positive attitude to the cynical words used by the teacher. It can be seen from the data of interview in cognitive component. In their opinion, cynical words used by the teacher can remind them about their mistake as well as their bad behavior. Unfortunately, although cynical words used by the teacher had positive impact on students, most of them admit that it hurts them. They feel sad and embarrass when the teacher disparages them in front of their classmate. Responding this case, it is better for the teacher to find another way in reminding the students' mistake. They can avoid using cynical words, especially if it is conducted in front of the class. They, here, can criticize students' mistake or behavior by using polite words. Concerning the last component of attitude, which is behavior, most of students state that they did not do anything in responding to the cynical words used by the teacher. However, they confess that it makes them to be better students by studying hard or changing bad behavior. This indicates that cynical words used by the teacher is quite effective to change the students' behavior or mistake.

\section{CONCLUSION}

Based on the result and discussion of this research it can be concluded that students basically had positive attitude to the cynical words used by the teacher in the classroom interaction. However, it is better for the teacher to not use it so often because it can harm the students 
feeling, especially if it is conducted in front of the class. Besides, it is better for the teacher to find the other way that is more appropriate and polite in rebuking or reminding the students' mistake. Therefore, the warm relationship between teacher and students can be maintained.

\section{ACKNOWLEDGMENTS}

Praise to God who has enabled me to finish this research paper. During compliting the paper the writer obtained many helps, suggestions, and motivations from many people. For that reason, the writer would like to express her gratitude to: Dr. H Heris Hendriana, M.Pd., the head of IKIP Siliwangi Bandung. Dr. Irma Savitri Sadikin, M.Pd, the head of English Education Study Program, and Gartika Pandu, M.Pd. as the first supervisor.

\section{REFERENCES}

Allport, G. . (1935). Attitudes. Worcester, Mass: Clark University Press.

Brown, H. . (2001). Teaching by Principles An Interactive Approach to Language Pedagogy (Second Edition). Pearson Education Company.

Ellis, R. (1994). The Study of Second Language Acquisition. Shanghai: Shanghai Foreign Language Education Press.

Jain, V. (2014). 3D Model of Attitude. International Journal of Advanced Research in Management and Social Sciences, 3(3), 1-12.

Korkut, A. (2016). Organizational Cynicism Levels of Teachers in Secondary Schools in Turkey / Türkiye ' deki Ortaokullarda Görev ..., 2(November), 91-112. https://doi.org/10.19160/e-ijer.85338

Myers, D. G. (1987). Social psychology (2nd ed.). New York: McGraw-Hill.

Pinter, A. (2006). Teaching Young Language Learners. Oxford: Oxford University Press.

Pujiastuti, R. T. (2013). Classroom Interaction: an Analysis of Teacher Talk and Student Talk in English for Young Learners (Eyl). Journal of English and Education, 1(1), 163-172.

Richard, J. . (1992). Longman Dictionary of Language Teaching \& Applied Linguistic. Beijing: Foreign Language Teaching and Research Press.

Schiffman, L.G. \& Kanuk, L. L. (2004). Consumer Behaviour 8th Ed. Upper Saddle River, NY: Pearson Education. 